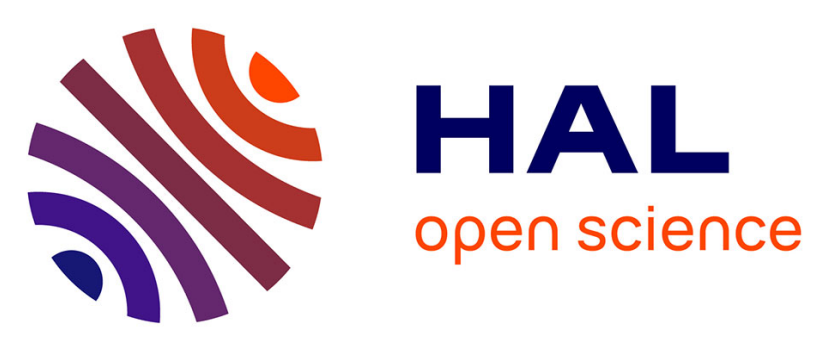

\title{
Assessment of the spatial variability of the added value on precipitation of convection-permitting simulation over the Iberian Peninsula using the RegIPSL regional earth system model
}

Namendra Kumar Shahi, Jan Polcher, Sophie Bastin, Romain Pennel, Lluís

Fita

\section{To cite this version:}

Namendra Kumar Shahi, Jan Polcher, Sophie Bastin, Romain Pennel, Lluís Fita. Assessment of the spatial variability of the added value on precipitation of convection-permitting simulation over the Iberian Peninsula using the RegIPSL regional earth system model. EGU General Assembly 2021, Apr 2021, Online, France. 10.5194/egusphere-egu21-9062 . insu-03560931

\section{HAL Id: insu-03560931 https://hal-insu.archives-ouvertes.fr/insu-03560931}

Submitted on 7 Feb 2022

HAL is a multi-disciplinary open access archive for the deposit and dissemination of scientific research documents, whether they are published or not. The documents may come from teaching and research institutions in France or abroad, or from public or private research centers.
L'archive ouverte pluridisciplinaire HAL, est destinée au dépôt et à la diffusion de documents scientifiques de niveau recherche, publiés ou non, émanant des établissements d'enseignement et de recherche français ou étrangers, des laboratoires publics ou privés. 
EGU21-9062, updated on 07 Feb 2022

https://doi.org/10.5194/egusphere-egu21-9062

EGU General Assembly 2021

(c) Author(s) 2022. This work is distributed under

the Creative Commons Attribution 4.0 License.

\title{
Assessment of the spatial variability of the added value on precipitation of convection-permitting simulation over the Iberian Peninsula using the RegIPSL regional earth system model
}

\author{
Namendra Kumar Shahi ${ }^{1}$, Jan Polcher ${ }^{1}$, Sophie Bastin ${ }^{2}$, Romain Pennel ${ }^{1}$, and Lluís Fita ${ }^{3}$ \\ ${ }^{1}$ CNRS-IPSL Laboratoire de Météorologie Dynamique, École Polytechnique, Palaiseau, France. \\ ${ }^{2}$ LATMOS/IPSL, UVSQ Université Paris-Saclay, Sorbonne Université, CNRS, Guyancourt, France. \\ ${ }^{3}$ Centro de Investigaciones del Mar y la Atmósfera (CIMA), CONICET-UBA, CNRS UMI- IFAECI, C. A. Buenos Aires, Argentina
}

In the frame of the European Climate Prediction system (EUCP) H2020 project and COordinated Regional climate Downscaling Experiment (CORDEX), we have performed the ERA-Interim driven regional climate simulations with the coupled atmosphere (WRF)-land surface (ORCHIDEE) RegIPSL model at $20 \mathrm{~km}$ (EUR20; with parameterized convection) and $3 \mathrm{~km}$ (SWE3; convectionpermitting/resolving) horizontal grid spacing over the Iberian Peninsula (IP) for the period of 2000-2009. The Iberian Peninsula is an area with a rich diversity of climates which is affected by several high impact extreme events such as droughts and flash floods for which the coupling processes between land surface and atmosphere play a key role. The aim of this first study is to evaluate the added value of the simulated mean and extreme precipitation in the convectionpermitting simulation compared to the coarser resolution simulation for the four seasons (DJF, MAM, JJA, and SON). Experiment is performed as a chain of simulations while the EUR20 simulation is forced by the 6-hourly ERA-Interim initial and lateral boundary conditions (IC-LBCs) and the SWE3 simulation is forced by the 3-hourly EUR20 simulated IC-LBCs. The SPREAD (5 km) and Iberia01 $(10 \mathrm{~km})$ high-resolution daily gridded mean precipitation have been used as reference datasets for the validation of the simulated precipitation.

We have not found any consistent improvement in the SWE3 simulation compared to the parent EUR20 simulation for the seasonal mean precipitation of the IP except the spatial variation over mountainous peaks. The analysis shows a lack of mean precipitation in the western and southern parts of the domain in the SWE3 which explains that on average over the whole domain, the spatial-temporal pattern of the observed mean precipitation is quantitatively better represented by the EUR20 than the SWE3 simulation. The added value of kilometer scale simulation over the driving coarser scale simulation is obtained at various indices; in the representation of the spatialtemporal distribution of the Kolmogorov-Smirnov (K-S) distance, wet-day frequency and intensity for each season at both resolutions i.e. downscaled $(3 \mathrm{~km})$ and upscaled $(20 \mathrm{~km})$, although the SWE3 simulation slightly underestimates the observed frequency and intensity of the wet-day precipitation. The improvement of finer scale simulation over the coarser resolution simulation has also been found in the spatial-temporal distribution of the heavy precipitation events. It has also been noted that the spatial-temporal distribution of precipitation for all metrics used varies 
slightly between the two observation datasets for all seasons, and it may be due to the different resolution of both datasets. The absence of sub-daily observed datasets did not allow us to further investigate the added value of the convective permitting simulation at hourly time scales, but we also noticed heavier hourly precipitation and a shift in the diurnal cycle. These results demonstrate a clear advantage of using a RegIPSL model at the kilometric scale over the IP in simulation for high impact weather events, consistently with previous studies over other areas. Further analysis will be done on the hydrological processes in response to these shifts of precipitation distribution between the two simulations. 